\title{
GEOLOGICAL SIGNIFICANCE OF MARINE MOLLUSKAN BEDS : EVIDENCE FROM SOUTHERN COASTAL ZONE OF SRI LANKA
}

\section{J. KATUPOTHA}

Department of Geography, University of Sri Jayewardenepura, Gangodawila, Nugegoda.

(Received : 24 December 1993, accepted : 23 June 1994)

\begin{abstract}
Mollusks are invertebrate animals that live in brackishwater or marine habitats. The diversity and complexity of these habitats are due to winds, waves, tides, bottom features, daytime illumination, geologic origin of shoreline and ecologic conditions of the oceans. Assembly of bivalve and univalve mollusks occur due to the eustatic changes and the prevalence of coastal hazards. Stratigraphic sequences of shell beds along the southern coast between Kalametiya Kalapuwa (lagoon) and Bundala Lewaya (salt pan) clearly indicate that shells have been piled up together with stone artifacts, pieces of pottery, human bones and other animal bones. These were caused by severe storm wave action on mounds in lagoon and lake bottoms, on sand dunes and headlands. The present study shows that the shell valves of lagoon, lake and channel beds (floors of marine and brackish pools) mostly accumulated in situ consequent to the lowering of sea level between 5030 - 4390 and 3930 - 3290y B.P.
\end{abstract}

Key words: Marine molluscs, shell beds, south coast

\section{INTRODUCTION}

Assemblance of bivalve and univalve mollusks occur due to eustatic changes and coastal hazards. They are used as a geoscientific tool to study former sea-level stands. ${ }^{1}$ Radiometric dating of the shells in different levels and quantitative analysis of their deposition sequences are helpful for this purpose. The present study attempts to reveal the geological significance of inland marine shell beds on the southern coast of Sri Lanka at a site between Kalametiya Kalapuwa and Bundala Lewaya in the dry zone (Fig. 1). The geological significance, extension and evolution of these shell beds have not previously been investigated.

\section{METHODS AND MATERIALS}

Extension of the shell beds was mapped based on detailed field investigations. From twenty locations, shell and soil samples were collected for geologic analysis between March and December 1992. Each sample contained $1.5+2.0$ kilogram of shell and shell debris. All locations and sample heights were leveled to mean sea-level (msl) using TC 1600 EDM (Electronic Distance Measurement) theodolite (Set 3 B Sokkia) by a government licensed surveyor.

Separation of the grain sizes of the soil samples was undertaken using a BS 410, Laboratory Test Sieve (Endecotts, London). Before separation of grain sizes, weighted amount of dried soil ( 125 - $150 \mathrm{~g}$ ) was treated with $20 \% \mathrm{HCl}$ to remove carbonates. The treated wet sample was dried in an oven at about $100^{\circ} \mathrm{C}$ for at least eight hours. Approximately $500-600 \mathrm{~g}$ shells were also cleaned by 


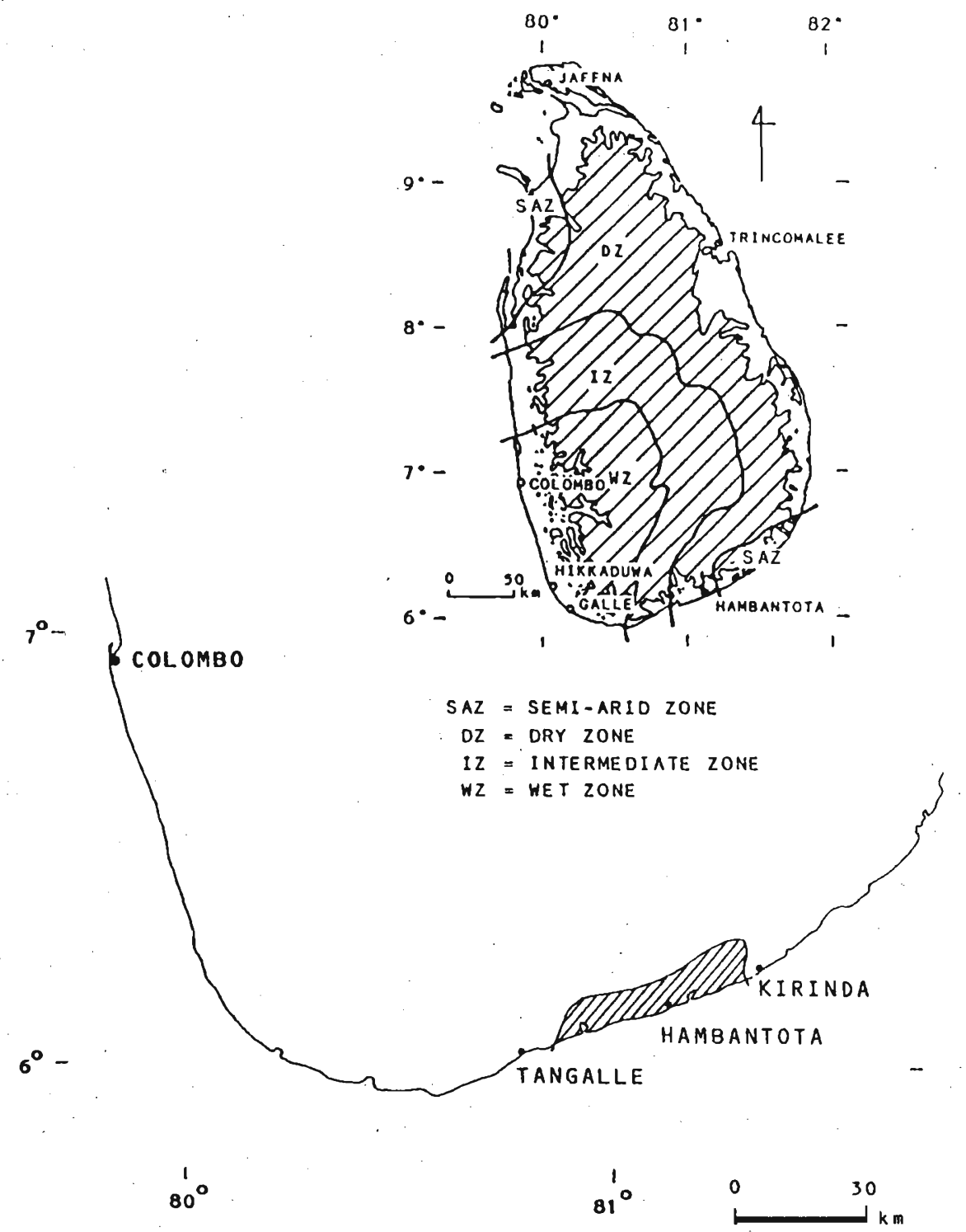

Figure 1: Location map of the shell bed areas along the southern coastal zone of Sri Lanka. 
treating with $10 \% \mathrm{HCl}$ for identification of the shells, and about $100 \mathrm{~g}$ were preserved for future radiometric dating. Colour of the soil samples and shell embedded soils was determined using the revised standard soil colour charts. ${ }^{2}$ The profiles of the shell layers were drawn using Harvard graphics. The laboratory work was conducted in the Department of Geography, University of Sri Jayewardenepura. Shells were identified with the help of a published catalogue. ${ }^{24}$

\section{Physical setting of the study area}

The study area, is situated between longitude $80^{\circ} 48^{\prime}-81^{0} 16^{\prime}$ and latitude $6^{0} 03^{\prime}$ $6^{0} 09^{\prime}$ Ambalangoda.and Hambantota topographic sheets $(1: 63,360)$ between Kalametiya Kalapuwa and Bundala Lewaya (Fig. 2 from a to k). Geologically the study area is underlain by the Highland complex rocks (undifferentiated rocks) on the western bank of the Walawe ganga, while the eastern bank lies on the Vijayan complex rocks (charnockite and charnockitic gneiss) of precambrian rocks. ${ }^{6}$ According to a Canada - Ceylon Colombo Plan Project (Resource of the Walawe Ganga basin?) the study sites consist of two types of rocks: (1) hornblende and biotite gneiss with associated pegmatite and migmatite (Vijayan complex rocks). (2) quartzo feldspathic gneiss and granulite (Khondalite series rocks). The zone of the quaternary deposits here are also somewhat narrow due to the extension of low hills and ridges close to the sea and lie on both Highland and Vijayan complex rocks. Broadly, the study area can be divided into three geomorphic units based on elevation and the composition of the deposits ${ }^{8}$ namely: (1) flat terrain (lowland $\mathrm{I},<30 \mathrm{~m}$, stope is $1 / 2^{\circ}$ or $1^{\circ}(60: 1$ or $100: 1$ in gradient). (2) flat to slightly undulating terrain (lowland II, $<30 \mathrm{~m}$ ). It has $1^{\circ}$ to $3^{\circ}$ slope or $60: 1$ to $20: 1$ gradient and can be designated as 'flood plain'. (3) undulating terrain (lowland III, $30-150 \mathrm{~m}$ ). Slightly undulating, undulating and rolling features appear particularly in the area between Udawalawe and Ridiyagama.

The shell beds are mainly concentrated in the flat terrain (lowland l) beyond the western and eastern sides of the Walawe ganga. The coastal belt which included lowland 1 has been altered by terrestrial, aeolien and marine processes, and has formed narrow and long beaches, beach ridges with medium $(3-5 \mathrm{~m})$ and somewhat high ( $8-12 \mathrm{~m})$ dunes. Sand spits are common features at the estuaries of the Walawe ganga and lagoons. Salterns, salt marshes and mangrove swamps and mound topography (a hummock relief) lie behind them. Too small and low bedrock outcrops appear as erosional remnants. The stony gravel beds and alluviam are the terrestrial deposits transported from upland and mountainous terrains. ${ }^{8}$

According to $\mathrm{K}$ öppen classification, ${ }^{9}$ the southern coastal zone, from Matara to Bundala is included into 'Afwi', 'Amwi' and 'Asi' climates. Distribution of rainfall of the Hambantota meteorological station shows two maximum seasons (Fig. 3) during the southwest monsoon (May to September) and convectionalcyclonic-depression (October to November). 

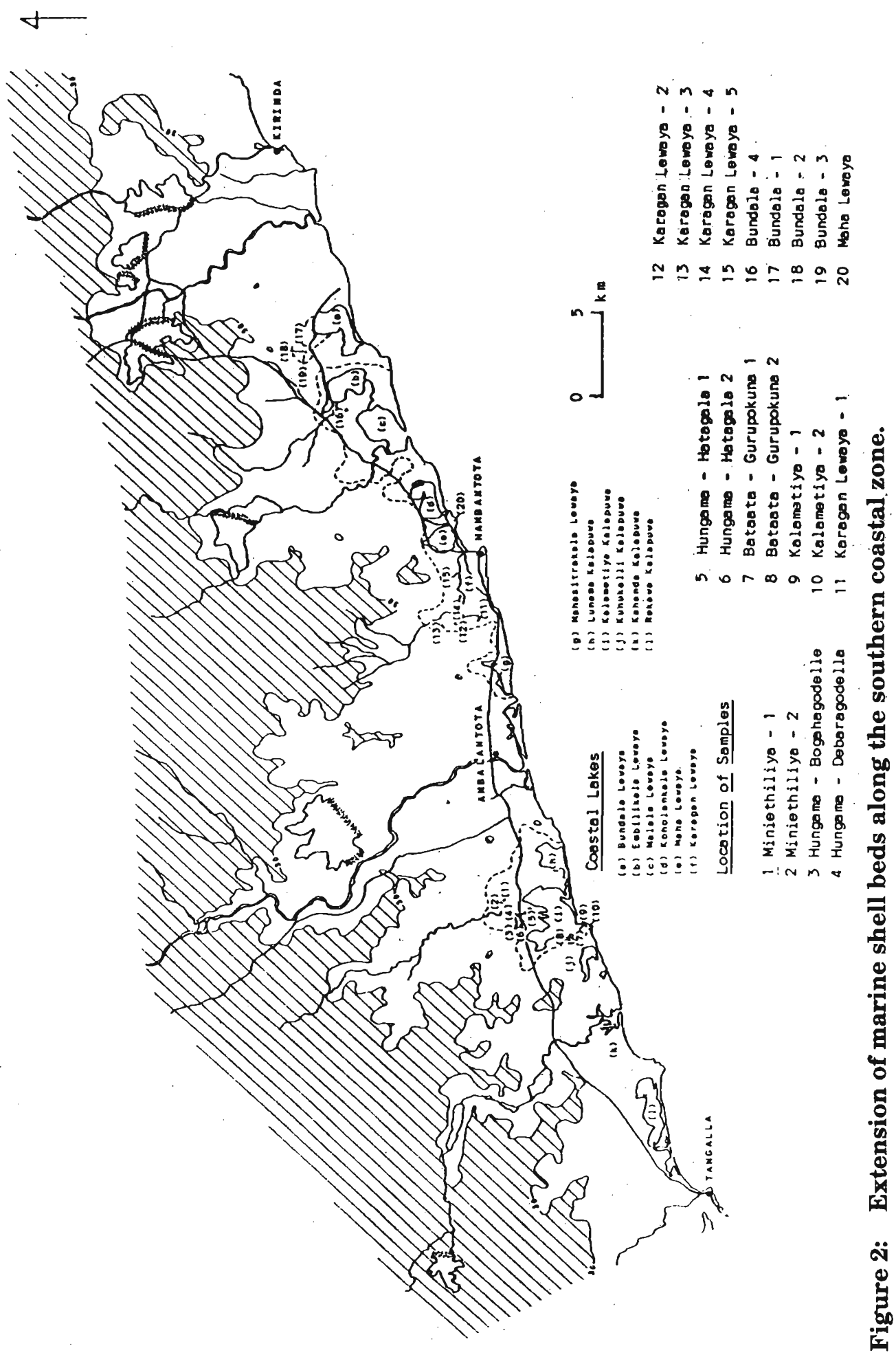


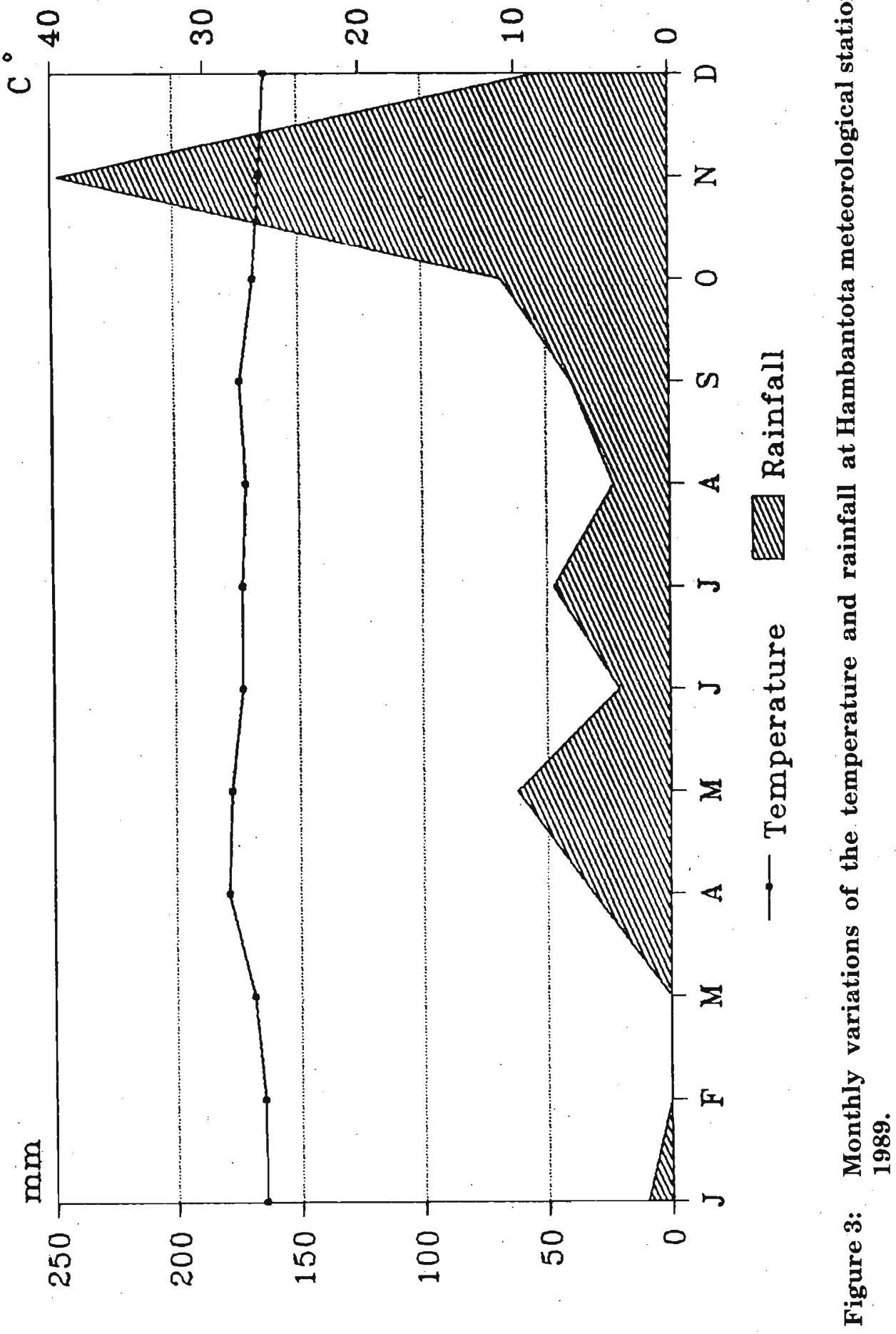


The soils of the study area have a close relationship with geologic characteristics, microrelief and the seasonal distribution of rainfall. Four main soil groups ${ }^{10}$ of the study area have been identified as follows: (1) reddish brown earths with high amount of gravel in subsoil \& low humic glay soils (2) reddish brown earths \& solodized solonetz (both (a) and (b) types lie on the undulating terrain) (3) alluvial soils of variable drainage and texture (flat valley bottoms, water logged areas etc. covered by these soils) (4) regosols on recent beach and dune sand. Barrier beaches, beach ridges, sand spits and dunes along the coast are formed by such materials. Rocknob plains and erosional remnants in the coastal plain are formed by granitic gneiss, quartzite, hornblende gneiss and hornblende - biotite gneissic rocks.

The coastal lowlands are covered by barren lands mainly sand dunes. Most of the dunes are covered by creeping vegetation (Spinifix littorerus; Smaharawana reula and Ipomoea pescaprae; S-mudubintamru) and scrublands. The wetlands behind the sand dunes are occupied by mangroves along the estuary of the Walawe ganga and around lakes and lagoons. Salt-pans, salt and brackishwater lakes of the area are subjected to daily tidal fluctuations. Sonneratia alba (S-kililla) is the dominant mangrove species of the area. Among other important mangroves are Nypa fructicans (S-ginpol), which extends along edges of lagoons and tidal creeks, Rhizophora (S-kadol), Bruguira (S-sirikanda) and Ceriops (S-kaduru) spp. Lowlands which are slightly above the mean high water springs level appear as freshwater marshes. Brackishwater and freshwater marshes are widely occupied by Typha angustifolia (S-hambupan) along the lower part of the Walawe basin. ${ }^{11}$

The undulating low ridge and valley topography $(30-150 \mathrm{~m})$, behind the coastal lowlands are covered by dry zone thorny forest and sparsely used croplands, homesteads and chena cultivation. The paddy lands have been concentrated in the fairly wide valley bottoms toward the inland form the coast.

\section{Marine mollusks as a sea-level indicator}

Sea-level indicators such as raised marine deposits, coastal barrier sands, beachrock, ooids; corals and reefs, coralline algae, marine notches, submerged forests marine mollusks etc. differ widely in indicative value (accuracy). They are important for the consideration of sea-level changes within the context of the geological development of an area. ${ }^{12}$

Mollusks are a group invertebrates that are terrestrial, brackishwater or marine in habitat. The diversity and complexity of their habitats are due to winds, waves, tides, bottom features, daytime illumination, geologic origin of shoreline and ecologic conditions of the oceans and create special zones (Fig. 4) for different shell species. ${ }^{2,3,13}$ The basic nature of the mollusks was determined millions of years ago as the great land continents were drifting into their present position. As the climate (atmospheric and oceanic), changed and vacillated, all species came under new challenges to their survival. ${ }^{2}$ The least adaptable are 
found today only as fossil remnants locked in tertiary beds; other populations were divided; isolated and changed into new species, while more resistant ones flourished and spread from terrestrial to pelagic areas. The phylum Molluska contains six classes viz; Monoplacophora, Amphineura, Gastropoda, Scaphopoda, Bivalvia and Cephalopoda.' Habe ${ }^{4}$ states that seven classes of mollusks including Aplacophora with the above six are composed of 112,000 species.

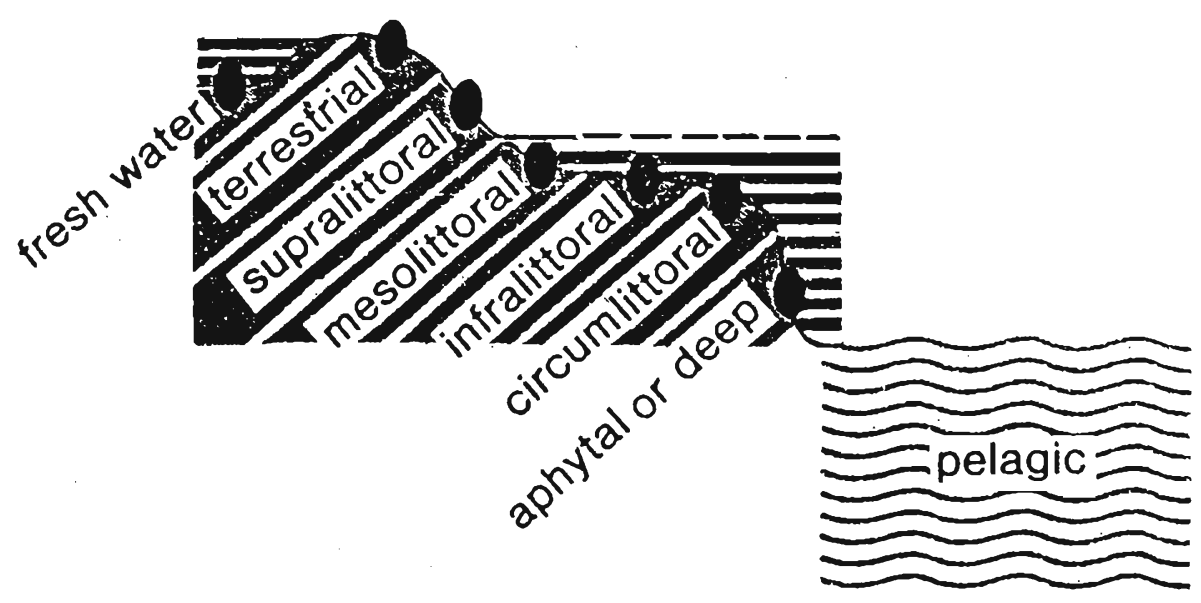

\section{Figure 4: Extension of marine molluskan zones between supralit- toral and circumlittoral.}

Aplacophora dates from the Lower Cambrian; the class has 10 species. The worm-shaped creatures have no shells. The Monoplacophora (Neopilina Class) well-known from the Palaeozoic deposits of epicontinental seas, are today only represented by those recently found from the deep sea, having a limpet-like (capshaped) shell. Scaphopoda (tusk shells), tube shaped shells which widen towards the aperture, are known from the Devonian period. The Bivalvia (Pelecypoda) are mainly found in areas close to the coast. The clams are covered with two shells. They are known from the lower Devonian. The Gastropoda are the most varied group within the molluska. They date from the Upper Cambrian. Cephalopoda (Squid and Octopus Class) are all predatory, swimming carnivores occurring in the major marine habitats. The Amphineura (Polyplacophora Chiton Class) are found from temperate to tropical areas and they usually live on rocky surfaces close to the shore. These date from the Ordovician to the present. These mollusks inhabit all the different regions of the sea, from cold polar regions to the warm equatorial belt, from surface water and intertidal beaches down to abyssal depths, but the warm shallow seas where reefs and rocks abound are thickly populated. 
The continental shelf around Sri Lanka comprises of submerged rocks, sand banks, sandstone and coral reefs. Most of these features are situated on the mesolittoral zone, known also as the intertidal zone (it extends from the hightide mark to the normal low-tide mark). Intralittoral plane extends from the lower limit of the mesolittoral to the lowest depths at which a certain family of plants occur. The seas around Sri Lanka provide an ideal environment for a rich variety of molluscan shells. Kirtisinghe ${ }^{13}$ has pointed out that research on sea shells of Sri Lanka orcur sporadically in zoological journals and the records of oceanographic surveys. He described about 530 species collected in the seas around Sri Lanka. ${ }^{13}$ Many of these are also found throughout the Arabian sea southward to the east of Australia, and along the coast of Australia.

Three types of marine mollusks are found in Sri Lanka ${ }^{13}$ : (1) Pelecypoda or bivalve mollusks (bivalvia by Peterson') (2) Gastropoda or snail-like mollusks and (3) Cephalopoda.

\section{RESULTS AND DISCUSSION}

\section{Microrelief of Shell Beds}

The extension of the whole shell beds along the southern coastal zone is laid in flat terrain, below $30 \mathrm{~m}$. This is somewhat wider than the coastal belt which is between south of the Kelani Ganga on the west coast and the Nilwala Ganga on the south coast. Both monsoons blow parallel to the coast, rather than across it, and the waves are largely constructive southerly swells. ${ }^{14}$ The coastal belt from Tangalle to Bundala is formed of narrow and long barrier beaches and beach ridges. Dune bearing barrier spits are common features at the outfalls of the Walawe Ganga and the circular shaped lagoons. Garnet and ilmenite sands are found in most shore deposits along the beach. Well drained and imperfectly drained soils occupy these areas.

The wetlands are covered by lagoons and lakes, salt marshes and mangrove swamps behind them. The lagoon and lakes are known locally as 'lewayas' and these are not fed by large streams. Most of them are very saline due to the persistent winds and dry climate. These conditions have been created by rapid evaporation. Slight undulatings of the area extend as lobes sloping towards the coast. Most of them appear as low outcrops along the coast.

\section{Geological Significance of the Shell Beds}

The shells were found to be concentrated in pockets around the Kalametiya kalapuwa, Hungama, Lumnama kalapuwa, Mahasittrakala lewaya, the area between Karagan lewaya, Pallemalala, Embilikala kalapuwa and Bundala lewaya. The extension of the shell beds is shown in Figure 2. Meretrix spp. are the dominant mollusks in the whole area. Beside this, Anadara spp. and Cerithidea spp. are also found mixed with Meretrix spp. or separately (Plate 1). Most of these are found in paddy fields, small mounds (hummocks), former embayments and the bottoms of lagoons, lakes and creeks. The shell beds at 
Hatagala extend up to Miniethiliya about 4 kilometres inland from the present coast. The shell beds at Hatagala - Ovitigoda yaya (paddy field) are composed of Meretrix spp. They are somewhat large (below $55 \mathrm{~mm}$ in size). Highly weathered pieces of elk bones and pottery fragments can be found from the mining pits (Plate 2a).

The shells at Miniethiliya are mined from small mounds near the paddy fields and small mounds slightly elevated from the paddy fields (Fig. 5, Location No. 1; Fig. 6, Location No. 2) about 0.5 ha. in size. Calcareous clay with sandy (little) soil (Grayish Gray Soil - 10 YR 4/2) contain in the top layer. Tiny and small to somewhat large size of shells can be found. Shells belong to Cerithidea spp. (below $20 \mathrm{~mm}$ ) and Meretrix spp. (below $40 \mathrm{~mm}$ in size). Elk bones (horn) together with Meretrix spp. were found in Location No. 2. Shell debris, sub-rounded quartzite pebbles, coarse to fine sand with clay and other animal remains are embedded in the deposits. Although the shell beds of the area are about 4 kilometres inland from the present coast, the thickness of the layer is considerably high. The beds at Hungama - Pallegama (Ihalagama Yaya) are also mixed with univalve shells, Anadara spp., Meretrix spp. pottery fragments and animal bones.

Similar features with very thick shell layers are found at Hatagala Bogahagodella (Fig. 7, Location No. 3; Plate 3). Most of these shell mounds are covered by thorn bushes and stunted trees. Shells, shell rubble mixed with calcareous sand and clay (Light Gray - $10 \mathrm{YR} 7 / 1$ ) in sample 1. The shell of sample 2 in the same location is mixed with Brownish Gray soil (10 YR 4/1). A pure quartz pebble was found in this sample. Shells belong to Cerithidea spp. is below $20 \mathrm{~mm}$ and Meretrix spp. is also below $20 \mathrm{~mm}$ in size (Plate 3). The shell beds at Debaragodella (Fig. 8, Location No. 4). are mixed with calcareous clay (Brownish Gray soil (7.5 YR 4/1) in sample 1. There are no pebbles or coarse sand, but pure quartz fragments are found. Calcareous clay with fine sand and shells (grayish brown soil - 7.5 YR 4/2) were in sample 2. The clay was compact when dry. The clams in live position were also found in this sample.

A coconut land at Hatagala (temple land, about 0.25 ha. in size) has a considerable amount of shells (Fig. 9, location No. 5). Tiny and small size to large size of shell gathered together with light gray sandy soil (10YR 7/1). Many Cerithidea spp. are well preserved and they are below $20 \mathrm{~mm}$ in size. Meretrix spp. of both samples are also below $55 \mathrm{~mm}$ in size. A thick shell layer of the mound has been mixed with stone pebbles (appear as artifacts), human bones, fragments of pottery etc. Highly weathered human skeletons were found at same mound of location No. 6 (Fig 10). A part of a jaw with teeth, vertebral columns, rib cages and radius are found in this location. The last teeth of the jaw indicate that the skull belonged to a young human. Other conditions of the site are very similar to location No. 5. Well polished oval-shaped stone artifacts, stone balls, human bones, a head of a serpent and other animal bones as well as pottery fragments are mixed with these shell beds (Plates $2 b, 4$ and $5 c$ ). 



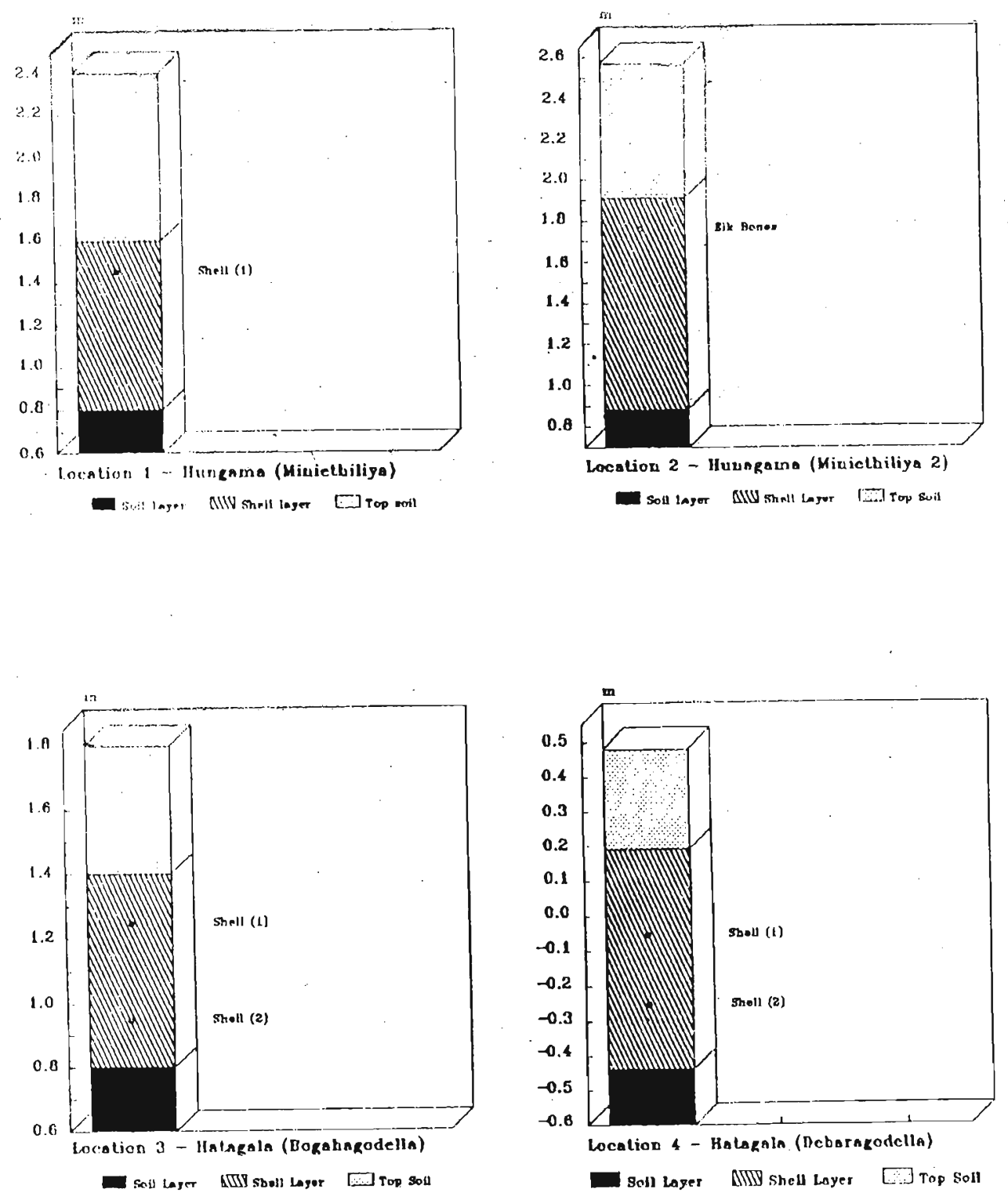

Figure 5, 6, 7 and 8: Stratigraphic sequences of the shell beds at location nos. 1,2 (Hungama - Miniethiliya), 3 (Hungama -Bogahagodella) and 4 (Hungama - Debaragodella). 




Plate 3: About $1 \mathrm{~m}$ thick shell layers at Hungama-Bogahagodella (location No. 3).

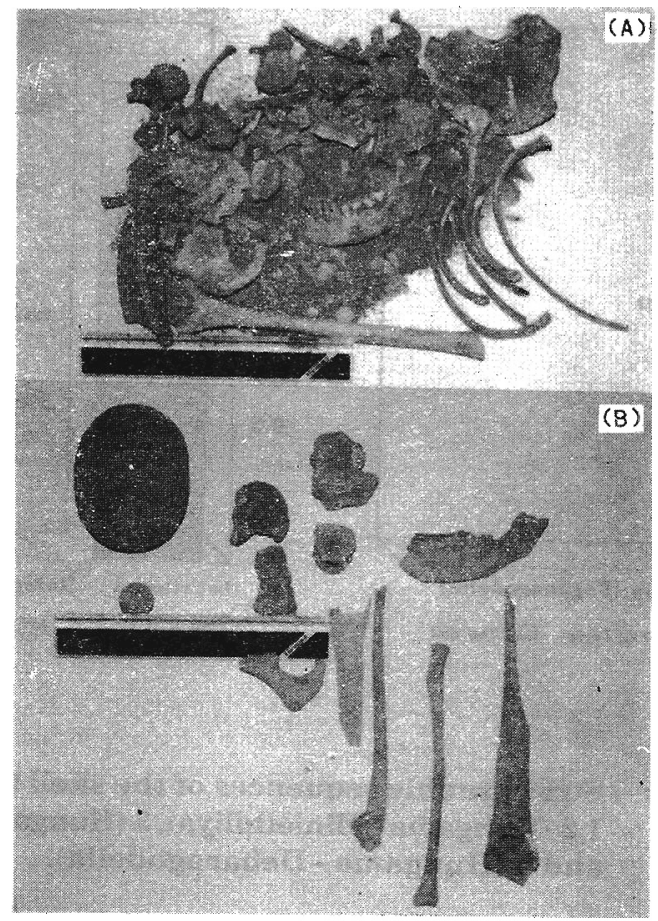

Plate 4: (A) Debris of human bones, (B) Human and other animal bones and stone artifacts from the shell beds at location no. $5 \& 6$. 


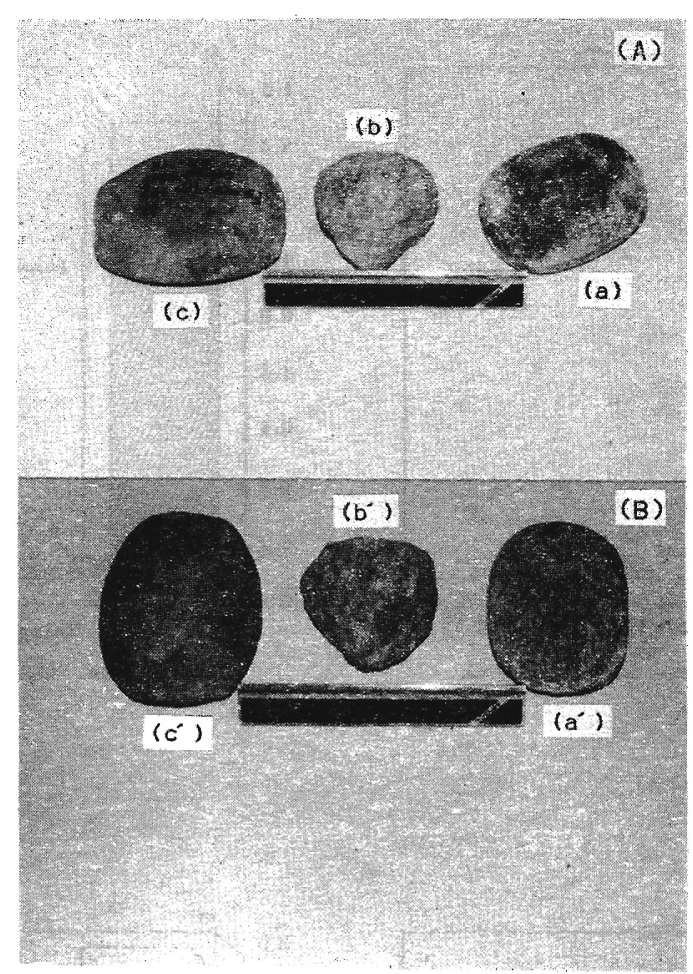

Plate 5: (A) Stone artifacts collected from the shell beds at location no.5 (c), Nabadewa (5b-same stone artefact of the Plate 9) and location no. 19 at Bungala (5a). $\cdot($ B) backside of the same stone artifacts (c', b' \& a').

Two distinctive beds at Bataata - Gurupokuna and Kalametiya have been deposited in morphologically different areas. The beds at Gurupokuna 1 (Fig. 11, location No, 7 \& Fig. 12, location No. 8) appear as about $3 \mathrm{~m}$ thick deposits (horizontally deposited) on mounds and a former lagoonal beach (Plate 6). Sample 1 belongs to light gray shelly sand (10 YR 7/1). Clear quartz fragments were in the sample. The size of the Meretrix spp. is below $35 \mathrm{~mm}$ and Cerithidea $\mathrm{spp}$. is below $25 \mathrm{~mm}$. Sample 2 contains light gray shelly sand (10 YR 7/1). The Meretrix spp. is small (below $30 \mathrm{~mm}$ ) and Cerithidea spp. appear as fragments. Unidentified shell fragments are also found here. Sample 3 of this location is classified as dull yellowish orange soil (10 YR 6/3). Meretrix spp. (below $50 \mathrm{~mm}$ in size) and somewhat weathered Cerithidea spp. (below $20 \mathrm{~mm}$ in size) are found. Sample 1 of the location No. 8 is mainly composed of light gray sandy soil (10 YR 7/1). Meretrix spp. of the sample is below 40 in size. Sample 2 is formed by dull yellowish brown soil (10 YR 4/3), sand and shell rubble. Cerethidea spp. (below $20 \mathrm{~mm}$ ). Meretrix spp. (below $40 \mathrm{~mm}$ ) and Anadara spp. (below $45 \mathrm{~mm}$ ) are the main shell types of this location. 



Figure 9, 10, 11 and 12: Stratigraphic sequences of the shell beds at Loc. Nos. 5, 6 (Hatagala - Temple Land), 7 (Bataata Gurupokuna) and 8 (Bataata - Gurupokuna). 

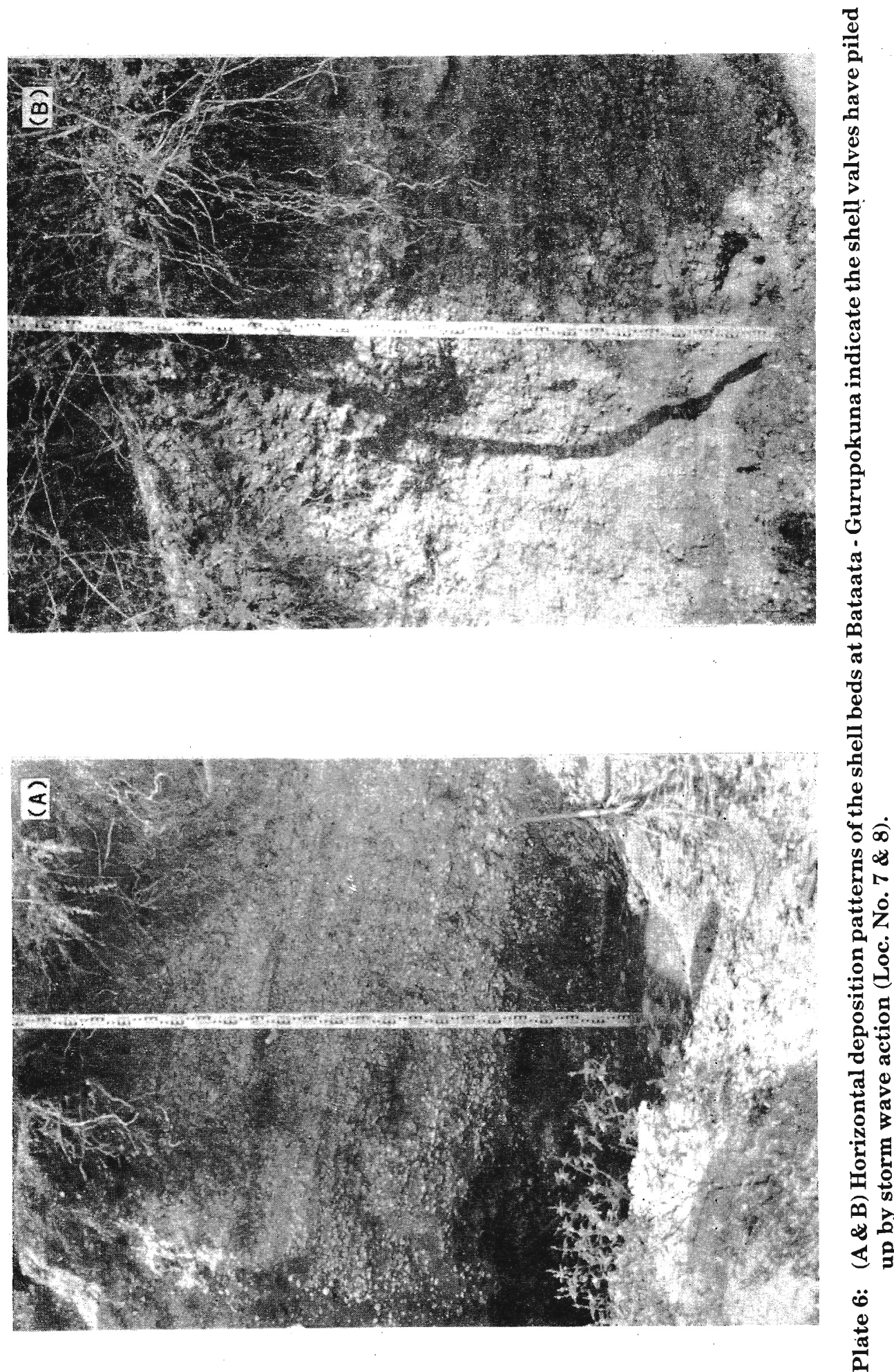
Kalametiya (Henagahapugala) beds (Fig: 13, Location No. 9) have been deposited on a rocky headland (with a thin soil cover) which is $13.8 \mathrm{~m}$ above mean sea level. The shells Meretrix spp. are below 40 in size. Broken large shells mixed together with brown soil ( 10 YR 4/3). Pottery fragments are also found. The shells are gathered even in rocky splits. Based on the deposition pattern there is a possible indication that shells were deposited in the area due to severe strong wave action (Plate 7b). At location no. 10, brown fine sand with clay (10 YR 4/3) with shell and shell fragments appear in both shell samples (Fig. 14). The shells belong to Meretrix spp. (below $40 \mathrm{~mm}$ in size other comments are same as location no. 9). Inorganic content and grain sizes of the soil sample (10.1) are shown in Figure 17. Many pieces of pottery are mixed with the shell bed in this area (Plate $7 \mathrm{a}$ ). The thickness and the height of the shell beds at Kalametiya (location nos. $9 \& 10$ ) are different to the other locations (Table 1). Eleven shell bearing microlayers can be identified at Kalametiya, on a former lagoon, and contain Meretrix and Cerithidea spp. This sample point is not levelled due to the physical obstacles (Fig. 18, Plates $7 \mathrm{~b}$ and 8).

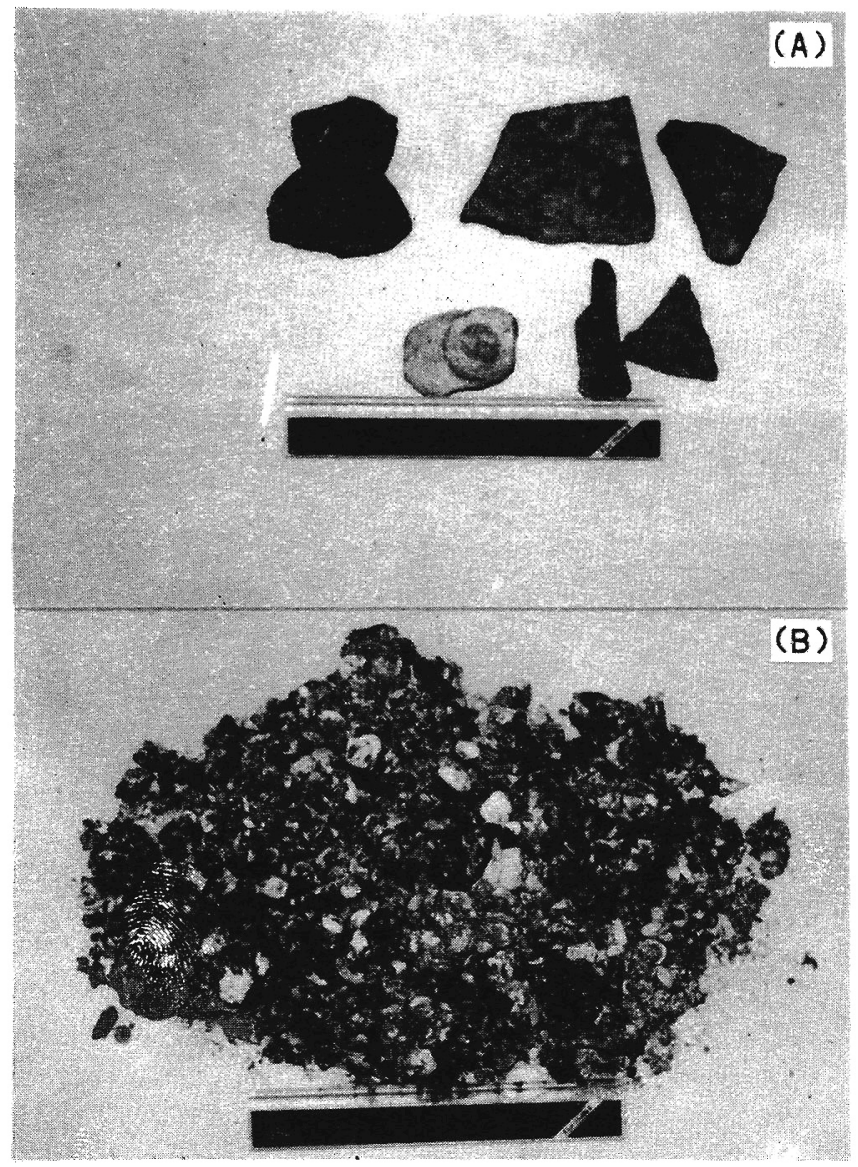

Plate 7: (A) Pieces of different types of pottery are found from the shell beds at Kalametiya (Loc. No. 9 \& 10). (B) Peaty-clay with shells contained in the last series of the separate pit Kalametiya (Plate 8). 

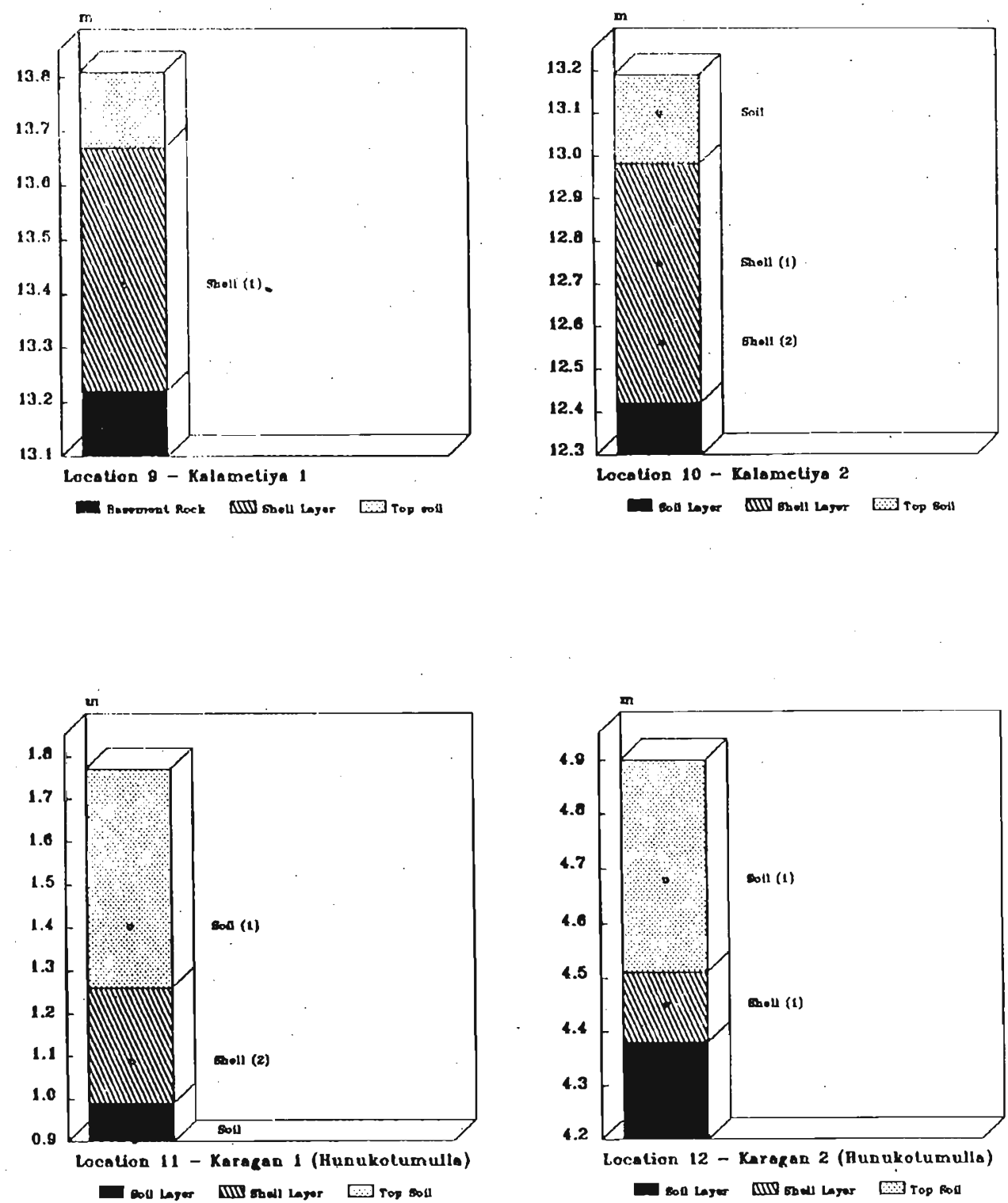

Figures 13, 14, 15 and 16: Stratigraphic sequences of the shell beds at location nos. 9, 10 (Kalametiya 1 and 2), 11 and 12 (Karagan 1and 2). 

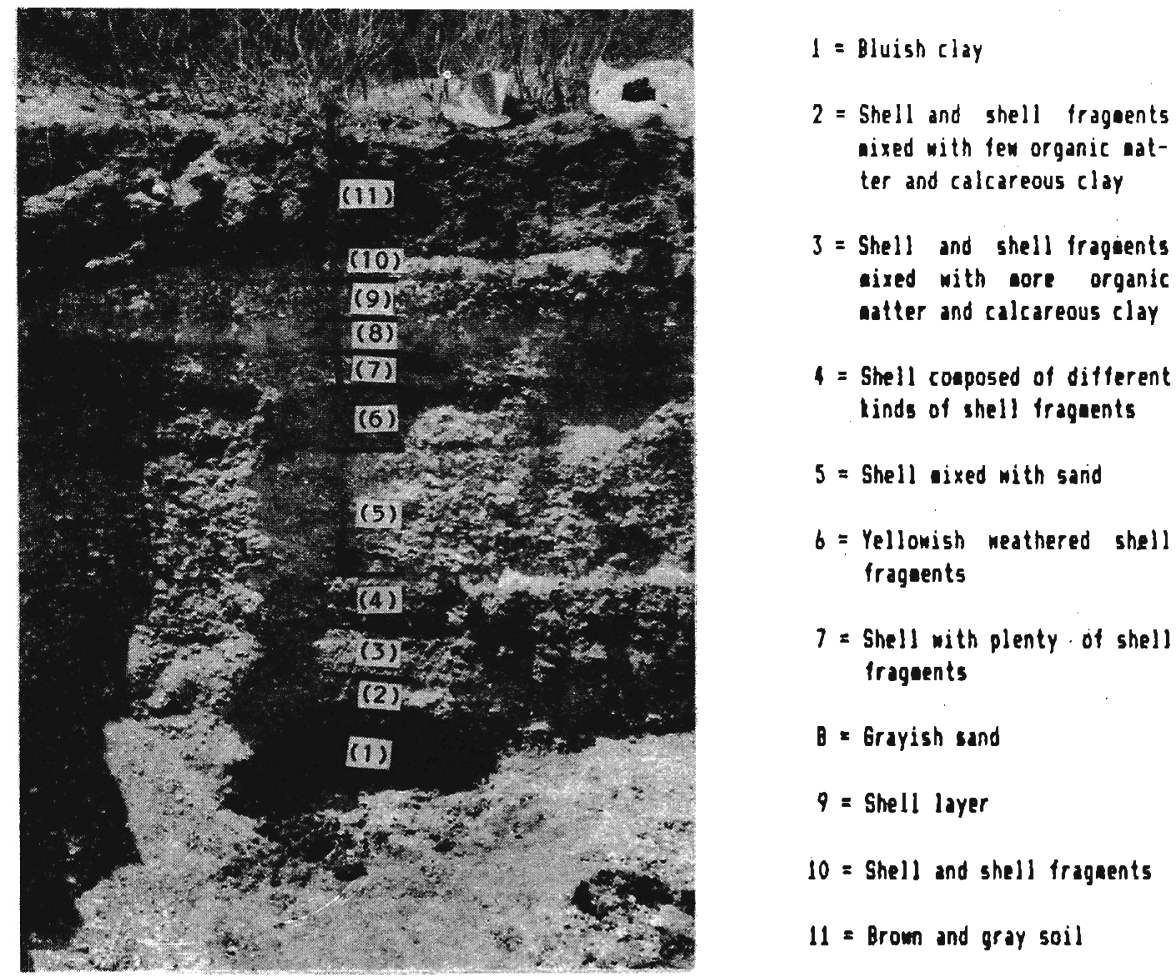

Plate 8: Stratigraphic sequences of the shell bed at Kalametiya. Eleven microlayers (series) are identified based on the type and size of shells and constituents of other materials.

The shells from Godawaya to Mirijjawela are deposited as small pockets in depressions (lagoon and lake bottoms) between sandy beach and undulating terrain which gradually increase in altitude inland. The beds at Kiula Kalapuwa consist of tiny and small to large Meretrix spp. They are below $50 \mathrm{~mm}$ in size. The top soil of the area is covered by dull yellowish brown medium to fine sand (10 YR 4/3). The soil layer which is below the shell layer contains medium to fine brown soil (10 YR 4/4).

Somewhat large shell beds are found at Hunukotumulla on former lagoon beaches as well as lagoon bottoms of the western bank of the Karagan Lewaya (Fig. 15, location no. 11), these can presently be seen as mounds. They are also covered by thorny bushes, stunted trees and grass. Sample 1 in this location is formed of 7.5 YR $4 / 2$ grayish brown medium to fine sand clay soil. The compact layer has weathered pebbles of iron. Grain sizes and content of inorganic matter of the sample 1 (11.1) are shown in Fig. 19. The shells have mixed with grayish 
brown soil (7.5 YR 4/2). Meretrix spp. are below $40 \mathrm{~mm}$ in size. Three shells are found in position of life ( $30 \mathrm{~mm}$ below in size). Somewhat compact, soil in sample 3 is grayish yellow brown (10 YR 4/2) in colour). Calcareous clay patches and weathered ironstone pebbles are found. Grain sizes and content of inorganic matter of the soil sample (11.3) are shown in Figure 19. Some beds at the Location No. 12 (Fig. 16) have deposited by wave action. The shells mix with Brown soil (7.5 YR 4/3) and fine sand and calcareous materials. Pebbles are very few. Plant remains are evident. Meretrix spp. (below $45 \mathrm{~mm}$ ) and Anadara spp. (below $65 \mathrm{~mm}$ ) are main shell types of the area. Grain sizes and inorganic content of the soil sample (12.1) are shown in Fig. 17.

The shell pockets in the northwestern area of the Karagan Lewaya (Fig. 20, location no. 13), Nelumpathvila compose of dull yellowish brown soil (10 YR 5/ 4) with fine sandy clay and shelly sand. Meretrix spp. of the sample is varied from small to somewhat large (below $40 \mathrm{~mm}$ ). The shell layer at location no. 14 Karagan 4 (Nelumpathvila) composed of dull yellowish brown soil (10 YR 5/4) with fine sandy clay and shelly sand (Fig. 21). Somewhat large Meretrix spp. are below $40 \mathrm{~mm}$. Sample 1 at the location no. 15 - Karagan 5 (Nelumpathvila) also contains brownish gray soil (10 YR 6/1) with calcareous sand and clay (Fig. 22). The shell layer is composed of dull yellowish brown soil (10 YR 5/4) with fine sandy clay and shelly sand. Meretrix spp. of the sample is somewhat large (below $40 \mathrm{~mm}$ ).

Extensive shell beds at Sippikulana, around the Maha lewaya and Koholankala (Koholankala lewaya) are found on slight undulatings (lobes). The shell layers here are thin compared to the beds at Gurupokuna, Hungama and the Karagan lewaya (Table 1). Furthermore, many shell patches are found in the area between Maha Lewaya and the Nabadewa, Pallemulla area, on the eastern bank of the Malala oya (Plates $5 \mathrm{~b}$ and 9 ). These shell beds are composed of stone artifacts and quartzite pebbles. Based on the colour of the quartzite pebbles, it is possible to infer that these may have been fired. Some beds are more than 4 $\mathrm{km}$ inland from the present coast.

A considerable amount of shell beds are found in the area between Malala lewaya and Embilikala kalapuwa (around Pallemalala, location no.16). These beds also appear on mounds and ditches of the area covered by scrublands and stunted trees. The shells at this location contain grayish brown soil (7.5 YR 4/2) with fine sand and clay, weathered pebbles, quartz fragments, plant remains. Meretrix spp. is below $45 \mathrm{~mm}$ and weathered Cerithidea spp. appear as fragments (Fig. 23). 


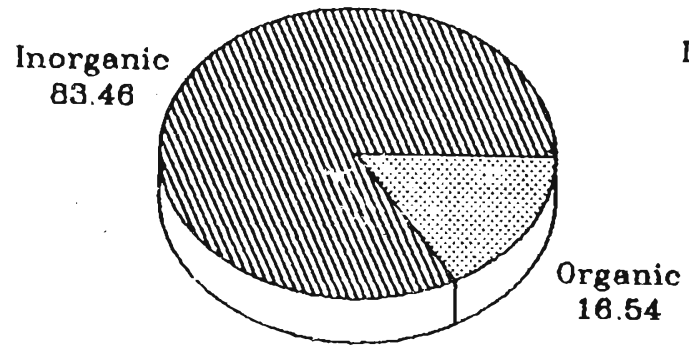

Sample No. $10(1)$

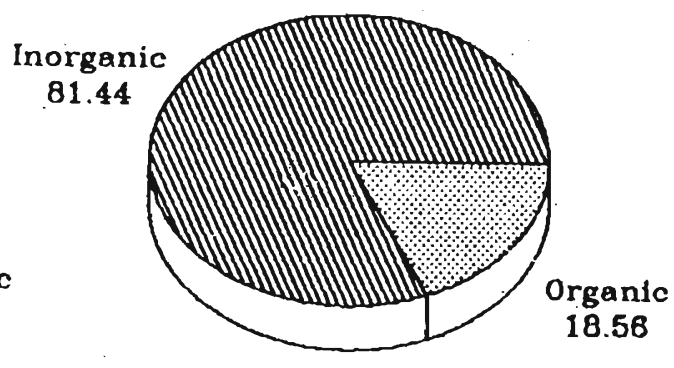

Sample No. $12(1)$

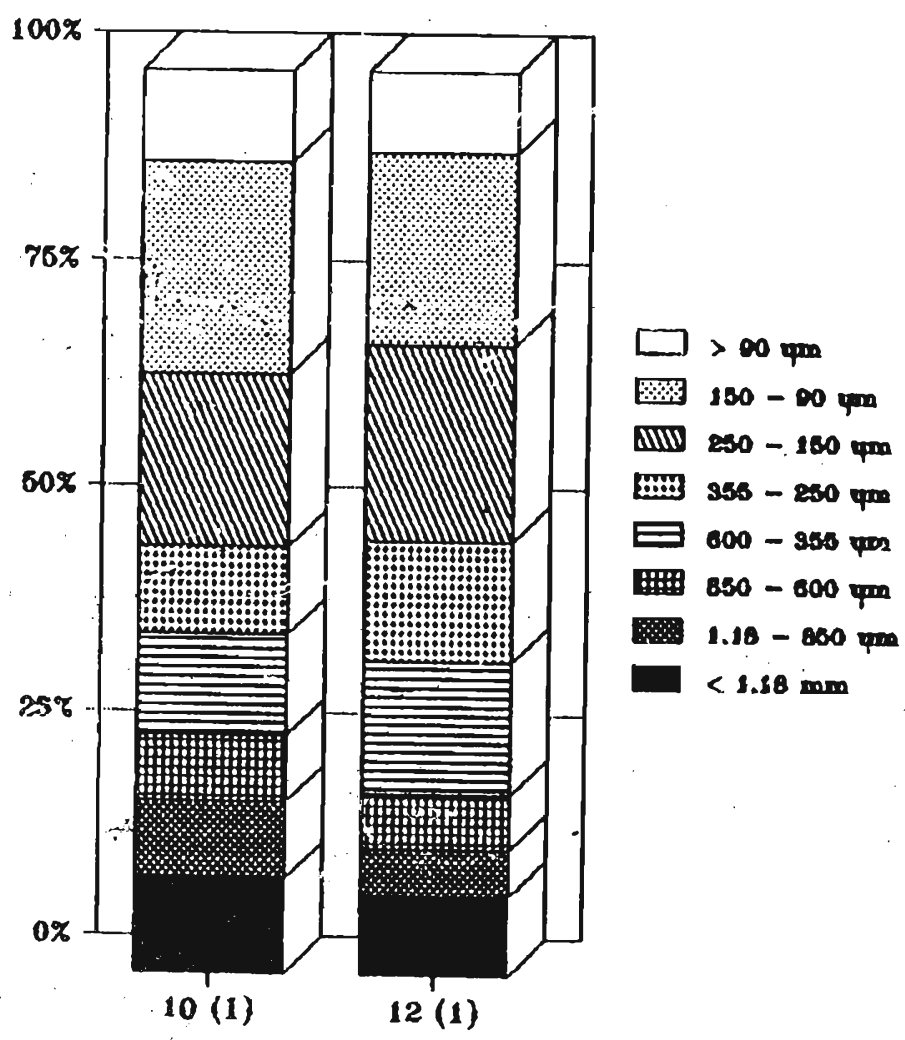

Figure 17: Inorganic contents and grain size analysis of the soil samples 10.1 and 12.1 . 




Plate 9: Glossy and well preserved shells and stone artifacts (quartzite) foundat Nagadewa, left bank of the Malala Area, about $4 \mathrm{~km}$ inland from the present coastline. Thick fertile alluvial soils overlain on the shell beds. 


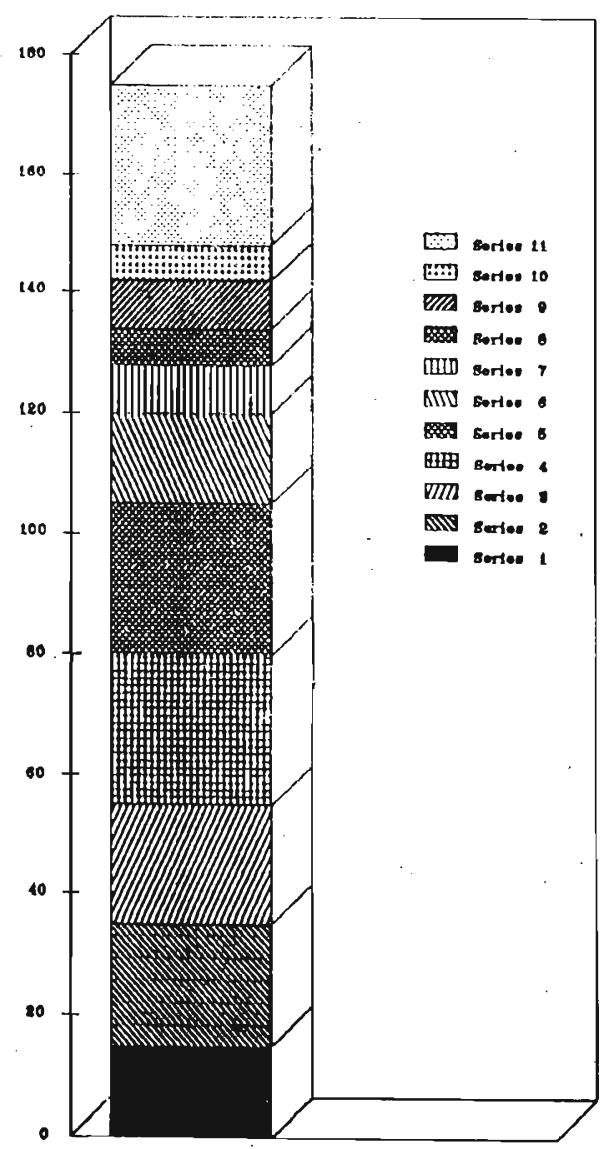

Figure 18: Stratigraphic sequences of the shell bed at Kalametiya.

Extensive shell beds are found in many mounds along the northern beach of Embilikala kalapuwa and on the side left of the Bundala road. The shell beds around Bundala lewaya are somewhat high and thick (Table 1) compared to the shell beds at Maha lewaya and Embilikala kalapuwa (location nos. 17,18 \& 19). Dark Brown medium sand to fine sand with clay soil (7.5 YR 3/3) appear at the location no. 17 - Bundala road 1 (near 4 th $\mathrm{km}$ ). The soil is somewhat compact. Plant roots and other organic matter are found. Damaged Meretrix spp. found here are below $30 \mathrm{~mm}$ in size. Weathered Cerithidea spp. found here are below $20 \mathrm{~mm}$ in size (Fig 24). Dark Brown medium sand to fine sand with clay soil (7.5 YR 3/3) of samples 1 \& 2 in location no. 18 - Bundala road 2 (near 4 th $\mathrm{km}$ ) is somewhat compact. Plant roots with other organic matter are found (Fig. 25). The shells (sample 3) have deposited with grayish brown soil (7.5 YR 4/2), medium to fine sand, calcareous, clay and feldspar pebbles (rare). Meretrix spp. found here are below $30 \mathrm{~mm}$ and weathered Cerithidea spp. are below $20 \mathrm{~mm}$ in size. Grain sizes and content of inorganic matter are shown in Figures 28(18.1) and (18.2). 
Table 1: Details of the Raised Shell Beds on the Southern Coast

\begin{tabular}{|c|c|c|c|c|c|}
\hline No & Location & $\begin{array}{c}\text { Lower level } \\
\text { of the } \\
\text { shell } \\
\text { layer } \\
\text { (metres) }\end{array}$ & $\begin{array}{c}\text { Ground } \\
\text { level } \\
\text { (metres) }\end{array}$ & $\begin{array}{l}\text { Thickness } \\
\text { of the } \\
\text { shell } \\
\text { layers } \\
\text { (metres) }\end{array}$ & Relief \\
\hline 1 & Miniethiliya 1 & 0.80 & 2.40 & 0.80 & mound \\
\hline 2 & Miniethiliya 2 & 0.87 & 2.56 & 1.03 & mound \\
\hline 3 & Hungama - Bogahagodella & 0.80 & 1.80 & 0.60 & mound \\
\hline 4 & Hungama - Debaragodella & -0.44 & 0.48 & 1.21 & mound \\
\hline 5 & Hungama - Hatagala & & & & \\
\hline & Temple Land 1 & -0.06 & 1.45 & 1.21 & mound \\
\hline 6 & Hungama - Hatagala & & & & \\
\hline & Temple Land 2 & -0.10 & 1.50 & 1.18 & mound \\
\hline 7 & Bataata - Gurupokuna & -0.90 & 1.50 & 3.00 & rocky mound \\
\hline 8 & Bataata-Gurupokuna & -0.50 & 1.90 & & rocky mound \\
\hline 9 & Kalametiya 1 & 13.25 & 13.80 & 0.45 & headland \\
\hline 10 & Kalametiya 2 & 12.40 & 13.20 & 0.60 & headland \\
\hline 11 & Karagan Lewaya 1 & 1.00 & 4.90 & 0.25 & lag. coast \\
\hline 12 & Karagan Lewaya 2 & 4.38 & 2.50 & 0.12 & mound \\
\hline 13 & Karagan Lewaya 3 & 1.30 & 2.50 & 0.40 & lag. coast \\
\hline 14 & Karagan Lewaya 4 & 1.54 & 1.50 & 0.56 & lag. coast \\
\hline 15 & Karagan Lewaya 5 & 1.00 & & 0.20 & lag. coast \\
\hline 16 & Bundala - Embilikala & 3.20 & 3.90 & 0.30 & mound \\
\hline 17 & Bundala Road 1 & 8.60 & 9.70 & 0.70 & mound \\
\hline 18 & Bundala Road 2 & 8.60 & 9.75 & 0.18 & mound \\
\hline 19 & Bundala Road 3 & 9.17 & 10.20 & 0.16 & mound \\
\hline 20 & Maha Lewaya & 3.08 & 3.65 & 0.17 & lag. coast \\
\hline
\end{tabular}

Source: Field Survey

Stratigraphic conditions, types of shells and the soils of the location no. 19 are as same as locations 17 and 18 (Fig. 26 and Plate 5b). Shells mix with dull yellowish brown soil (10 YR 4/3) at the location no. 20 - Maha Lewaya (Koholankala) with calcareous clay. Well preserved Meretrix spp. of the sample is below $35 \mathrm{~mm}$ in size (Fig. 27). They are also deposited on former lagoon beaches. The top soil (alluvial) cover of the Bundala area is about $1.5 \mathrm{~m}$ thick. In location No. 20 at Maha Lewaya (Koholankala) the shells are mixed with dull yellowish brown soil (10 YR 4/3) with calcareous clay. Well preserved Meretrix spp. of the sample here are below $35 \mathrm{~mm}$ in size. Present extension of the shell beds indicated that they have been deposited on mounds, along the lagoon and lake beaches as well as in lagoon and lake bottoms. Most of the beds are presently covered by superficial deposits (alluvium and wind blown sand). 


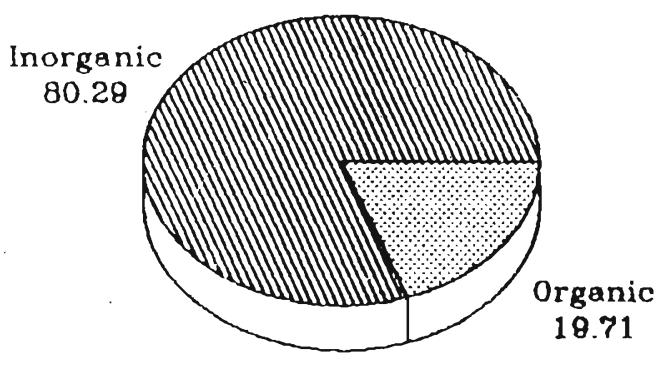

Sample No. 11 (1)



30.63

Sample No. 11 (3)

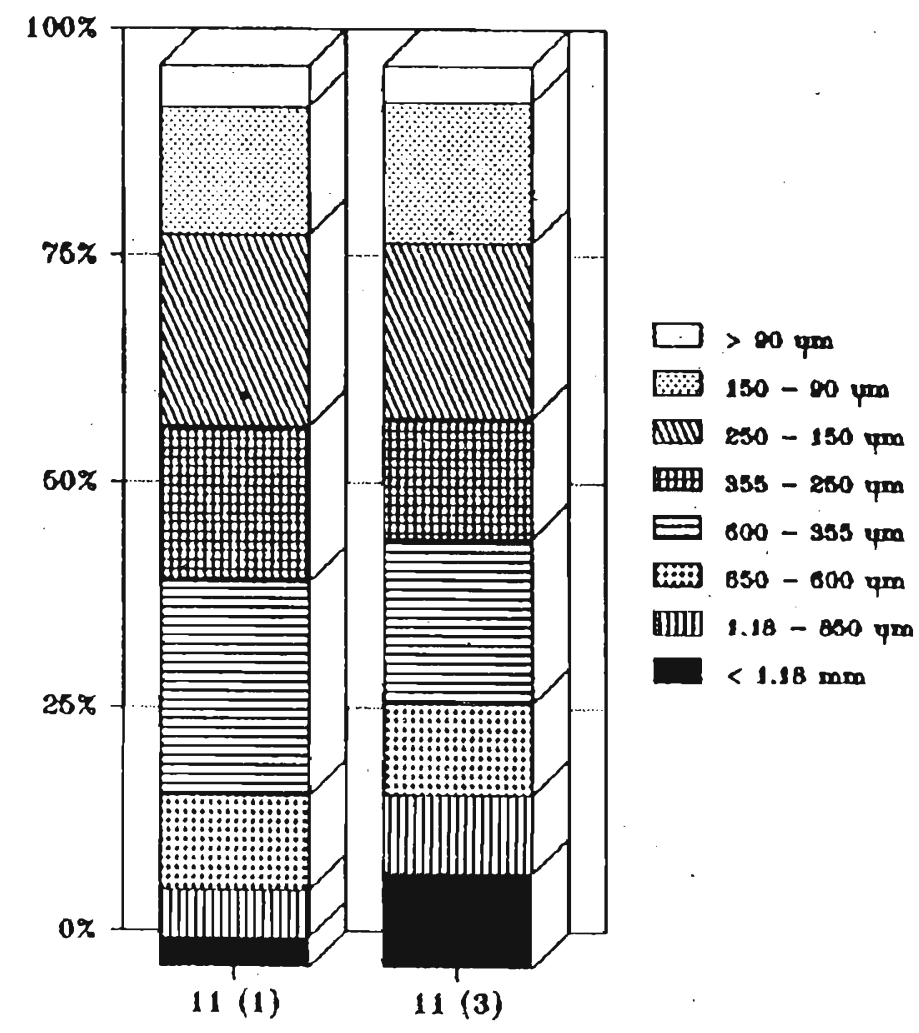

Figure 19: Inorganic contents and grain size analysis of the soil samples 11.1 and 11.2. 

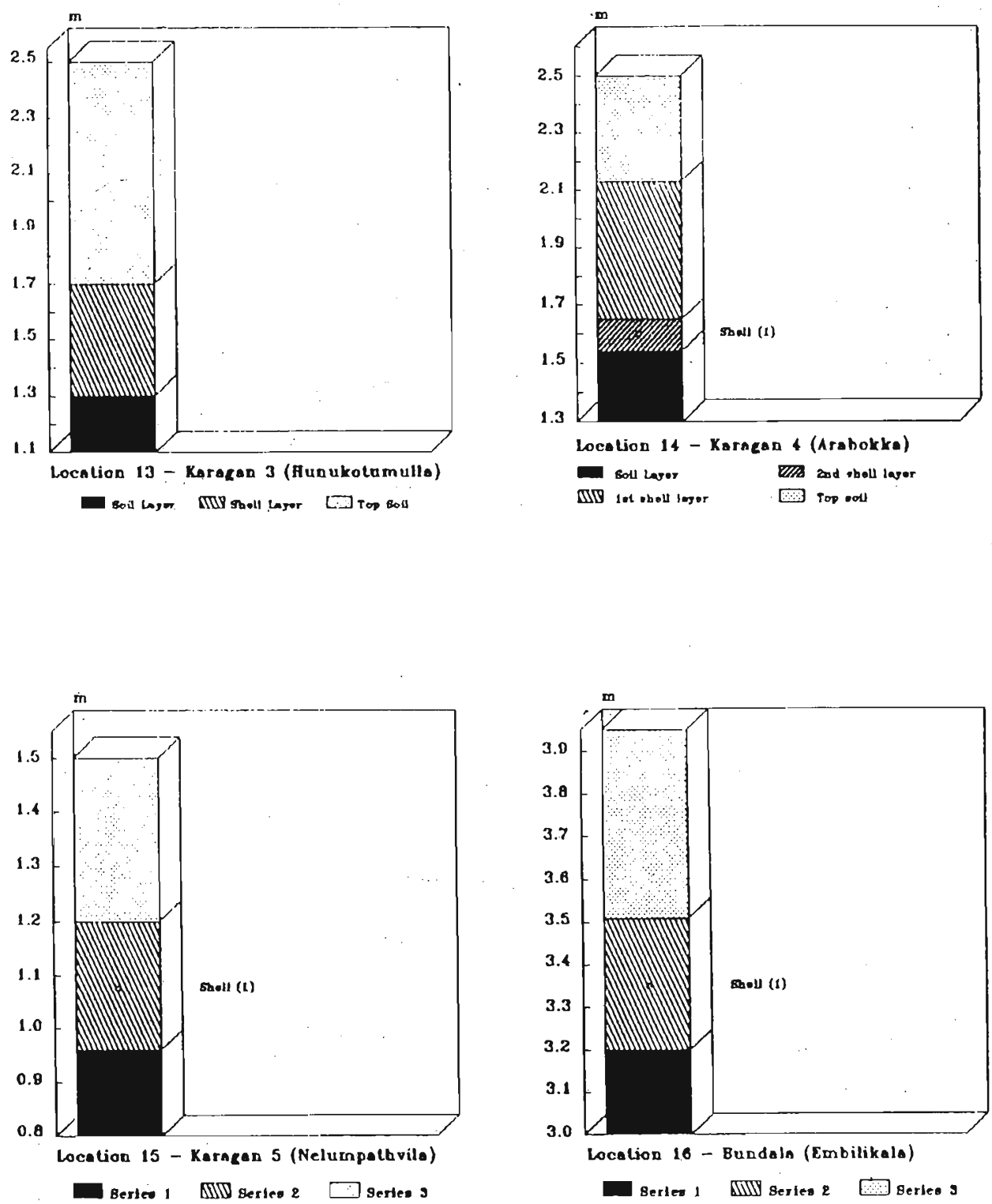

Figures 20, 21, 22 and 23: Stratigraphic sequences of the shell beds at location nos. 13, 14, 15 (Karagan 3,4 and 5) and 16 (Bundala 1). 

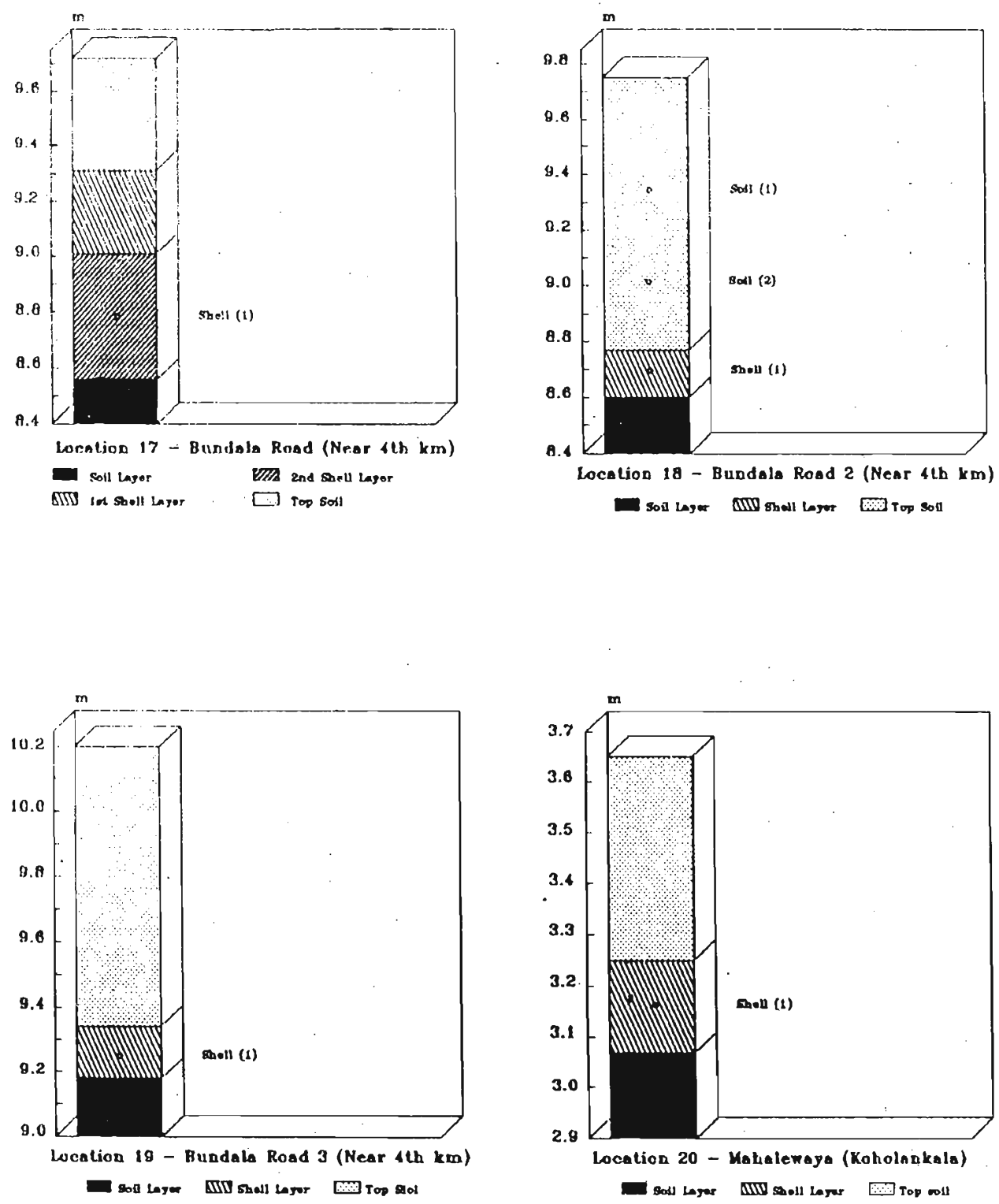

Figures 24, 25, 26 and 27: Stratigraphic sequences of the shell beds at location nos. 17, 18, 19 (Bundala Road 2) and 20 (Koholankala). 




Sample No. $18(1)$

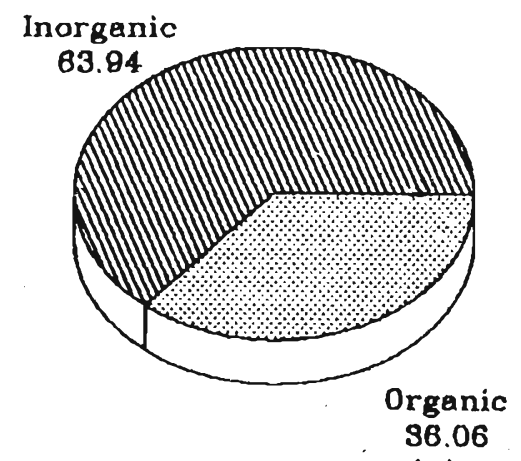

Sample No. $18(2)$

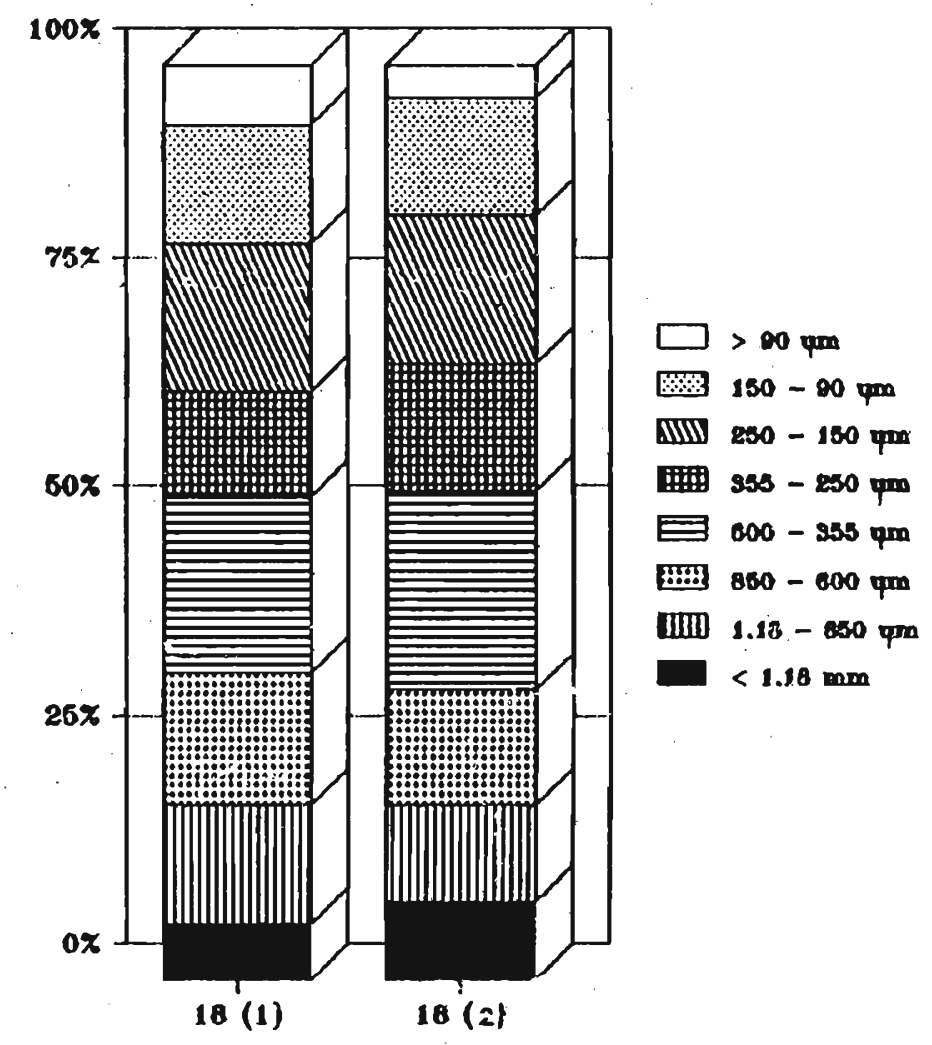

Figure 28: Inorganic contents and grain size analysis of the soil samples 18.1 and 18.2. 


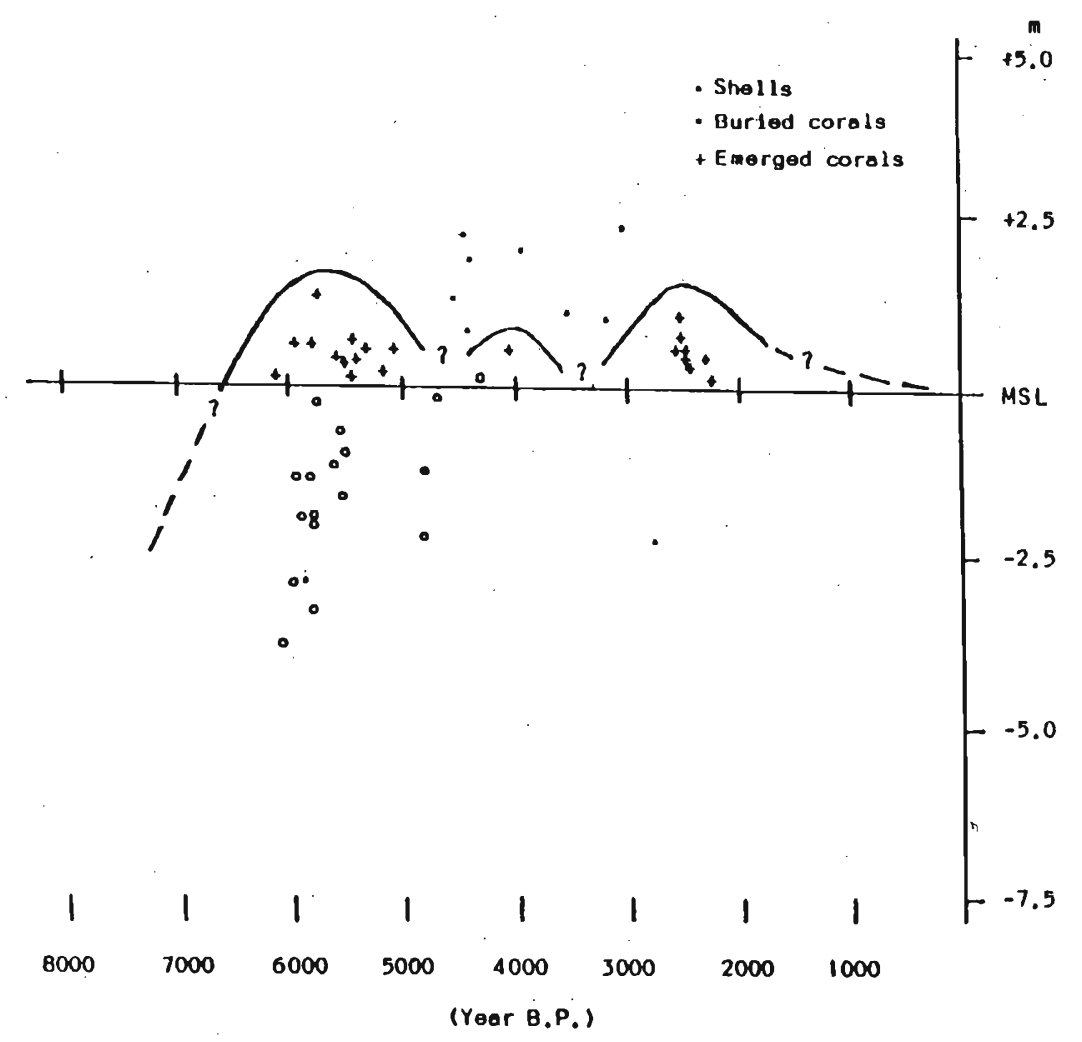

Figure 29: Curve indicates three episodes of high sea-level in Sri Lanka..

The shells of the study area belong mainly to three families: Veneridae (Venus clams), Arcidae (Ark shells) and Potamididae (Horn shells). The Veneridae is a large and well-known family of hard-shelled clams (strong and glossy). The shell valves in the beds from Kalametiya Kalapuwa to Bundala Kalapuwa belong to a few species; of which the dominant species in Meretrix meretrix (Plate 1). The family Arcidae are heavy, squarish, porcelainous clams having a so-called taxodant hinge - a straight hinge with numerous small teeth, about the same size. Most common ark shell species live in warm waters in sandy or muddy areas, while a few are found near coral reefs. The shells of this family of the study area belong to Anadara granosa or Anadara uropygmelana (Plate 1). The Potamididae included into Cerithidea cingulata (Gmelin, 1791) or Cerithidea ornata (Plate 1) is a large brackish water group with elongate, solid shells usually dirty brown in colour and many whorled. Most columella live in mangrove and estuarine areas. 
The levels of the shell layers, types of the constituents, colour of the soil etc. are described in detail, and shown in Figures 5 to 28 and Plates 1 to 9. The types of shells, live position of the valves, rocky artifacts, animal bones, and human bones which were found from these shell beds are shown in these plates. Many layers of different thickness of constituents and deposition patterns indicate that the shell and shell fragments have been deposited by storm waves especially at Bataata - Gruupokuna (Plate 6). The shell beds at Kalametiya which appeared in many micro-layers can be identified based on the deposition pattern (Plates $7 \mathrm{~b}$ and 8 ). The top shell layers contained tiny and small to large shells (below 40 $\mathrm{mm}$ in size) of Meretrix spp. and Cerethedea spp. with calcareous sand which had been piled up by wave action, while the lower layers contained weathered shells and shell fragments. They are mixed with weathered organic material (10 YR $2 / 1$ ) and calcareous clay. Bluish clay of the bottom layer indicates that the shells have been deposited on a grass biomass.

\section{Emerged Shell Beds and Their Relationship to Sea-level Change}

Katupoth ${ }^{15}$ recently indicated that the mid-Holocene sea-level was at least $1.5 \mathrm{~m}$ above that of the present level with three episodes as follows;

a) $6240-5130$ B.P. (first episode of high sea level)

b) 4390 - 3930 B.P. (second episode of high sea level)

c) 3280 - 2270 B.P. (third episode of high sea level)

Following these high sea-level episodes, the former drainage basins were submerged forming lagoon and lakes further inland, sometimes 3 to $4 \mathrm{~km}$ inland from the present coast. The undulating lobes which were extended towards the coast and outcrops became headland. As a result, headland-bay-beaches were created in many areas along the southern coast. Furthermore, the corals presently being buried between Akurala and Matara thrived on such embayments where factors were suitable for the growth of coral especially on the southwestern and southern coast, while mollusks lived in intermediate and dry zone coastal embayments.

It is suggested that the beachrock; slightly above from the supratidal zone, on the west coast had developed around 3,700 y B.P. during this stage. As evidenced from ${ }^{14} \mathrm{C}$ dating of shells embedded in emerged reef patche $\mathrm{s}^{16,17}$ and corals (in a position of growth) from emerged reef patches ${ }^{17-19}$ the climatic changes have occurred after the mid-Holocene high sea-level. The lowering of sea level can be recognized between $5030-4390$ y B.P. and $3930-3290$ y B.P. by ${ }^{14} \mathrm{C}$ dating of shell beds (Fig. 29 and Table 2). 
Table 2: Dated Shell Beds along the Southern Coastal Zone

\begin{tabular}{llccc}
\hline No & Locality & $\begin{array}{c}\text { Elevation } \\
\text { (in metres) }\end{array}$ & $\begin{array}{c}\text { Age (yr B.P.) } \\
\text { (half-life }= \\
5568 \pm 30\end{array}$ & $\begin{array}{c}\text { Laboratory } \\
\text { No }\end{array}$ \\
\hline 1. & Hungama & +1.3 & $5780 \pm 20$ & HR 120 \\
2 & Hungama & +0.8 & $4440 \pm 60$ & HR 264 \\
3 & Kalametiya & +1.2 & $3570 \pm 60$ & HR 265 \\
4 & Kalametiya & +2.2 & $4460 \pm 60$ & HR 266 \\
5 & Kalametiya & +2.0 & $3960 \pm 60$ & HR 267 \\
6 & Karagan & +2.3 & $3050 \pm 100$ & HR 123 \\
7 & Udamalala & +6.5 & $4050 \pm 60$ & HR 122 \\
8 & Udamalala & +5.0 & $4650 \pm 70$ & HR 268 \\
\hline
\end{tabular}

Source: Katupotha $1988 \mathrm{~b}$ and $1988 \mathrm{c}$.

The bulk of the shells of these beds have been piled up by severe storm wave action on mounds, in lagoon, lake bottoms and on sand dunes and headlands. Present investigations indicate further that the shell valves of lagoon, lake and channel beds (floors of marine and brackish pools) mostly accumulated as in situ consequently on the lowering of sea level. Hence, the sea level around 4700 and 3600 y B.P. was at its present level or slightly below it. Further, ${ }^{14} \mathrm{C}$ dating of shell beds along the southern coast in the Hambantota district prove such changes have occurred during the late Holocene. ${ }^{17,18}$

Furthermore, the deposits had been intermittently covered by vast quantities of coral and/or shelly sand and various types of debris moved by severe monsoon waves. This is shown, in Miniethiliya, Hatagala, Bataata - Gurupokuna, Kalametiya, Hunukotumulla, Nelumpathvila, Nabadewa and around Malala lewaya areas. The colour and constituents of the layers show that they are subject to local weathering conditions. Thickness of the top soil covered by these means varies locally and sometimes more than $1 \mathrm{~m}$ thick alluvial soil underline the shell beds. The deposition sequences of some shell patches of the mounds at Udamalala and on dune deposits help to infer that the valves have been discarded by early inhabitants and animals.

\section{Conclusion}

Stratigraphic sequences of the emerged Holocene shell beds along the southern coast between Kalametiya kalapuwa and Bundala lewaya clearly show that they are marine in origin. The shells of many of these beds have been piled up together with stone artifacts, pieces of pottery, human bones and other animal bones by severe storm wave action on mounds in lagoon and lake bottoms, on sand dunes and headlands. Present investigations of these shell beds further indicate that the shell valves of lagoon, lake and channel beds (floors of marine and brackish 
pools) mostly accumulated in situ consequently to the lowering of sea level between 5030-4390 and 3930-3290y B.P. The deposition sequences of some shell patches of the mounds at Udamalala and on dune deposits help to infer that the valves have been discarded by early inhabitants and animals. The deposition pattern and different types of artifacts are valuable indicators in the study of geological, archaeological and palaeoenvironmental significance of these beds.

\section{Acknowledgement}

The author thanks P. Ekanayake for helping in the field survey. This study was supported by the Natural Resources, Energy and Science Authority (RG/90/E/01).

\section{References}

1. Perterson K.S. (1986). Marine mollusks as indicators of former sea-level stands. In: Sea-Level Research : a manual for the collection and evaluation of data. (Ed. Orson van de Plassche ) pp 129-156, Geo Books, Great Britain.

2. Revised Standard Soil Colour Chart. 1976. Japan.

3. Abbott R.T. (1991), Seashells of Southeast Asia. Graham Brash, Singapore.

4. Sabelli B. (1980). Guide to Shells. (Ed. Harolds S. Feinberg). Simon and Schuster, New York.

5. Habe T. (1978). Shells of Japan. Hoikusha, Osaka, Japan.

6. Cooray P.G. (1984). An Introduction to the Geology of Sri Lanka. (2nd ed revised), Ceylon National Museum Publication, Colombo.

7. Canada - Ceylon Colombo Plan Project (1960). Resources of the Walawe Ganga Basin. The Government Press, Ceylon.

8. Katupotha J. (1992). Geomorphic Surfaces of the River Basins along the Western and Southern Parts of Sri Lanka. NARESA, Unpublished Report.

9. Thambyapillay G. (1960). Climatic regions of Ceylon-1 : according to the Koppen classification. Tropical Agriculturist CXVI, 147-177.

10. Survey Department of Sri Lanka (1977). Soil Map of Sri Lanka.

11. Plassche O. Van de. (1986). Sea level research: a manual for the collection and evaluation of data. Geo Books, Norwich.

12. Whitton D.G.A. \& Brooks, J.R.V. (1983). A Dictionary of Geology. Pengnin Books, Hazell Watson \& Vinerry, Great Britain. 
13. Kirtisinghe P. (1974). Sea shells of Sri Lanka. Chales E. Tuttle, Tokyo, Japan.

14. Swan B. (1982). The Coastal Geomorphology of Sri Lanka: An Introductory Survey. Armidale, N.S.W., pp 84-89.

15. Katupotha J. (1992b). New evidence of Holocene sea-level changes of Sri Lanka. Journal of the Geological Society of Sri Lanka 4: 39-44.

16. Hubbs L.C., Bien, S.C. and Suess, E.H. (1962). La Jolla National Radiocarbon Measurement 11, Radiocarbon 4: 204-238.

17. Katupotha J. (1988a). Hiroshima University Radiocarbon dates-1, West and South coasts of Sri Lanka. Radiocarbon 30 (1):125-128.

18. Katupotha J. (1988b). Hiroshima University Radiocarbon dates-2, West and South coasts of Sri Lanka. Radiocarbon 30 (3): 314-326.

19. Katupotha J. \& Fujiwara K. (1988). Holocene sea level changes on the southwest and south coasts of Sri Lanka. Palaeogeography Palaeoclimatology and Palaeoecology 68: 189-202.

20. Katupotha J. \& Wijayananda N.P. (1989). Chronology of the inland shell deposits on the southern coast of Sri Lanka. Quaternary Research 32: 222228. 